\title{
ENSURING THE CENTRAL BANK DISCRETION IN ISSUING STABILIZATION LOANS IN TIMES OF COVID-19 PANDEMIC
}

GARANTIZAR LA DISCRECIÓN DEL BANCO CENTRAL EN LA EMISIÓN DE PRÉSTAMOS DE ESTABILIZACIÓN EN TIEMPOS DE LA PANDEMIA DEL COVID-19

\author{
Oleg Podtserkovnyi* \\ Kristina Vozniakovska **
}

\begin{abstract}
Restrictive measures imposed by governments around the world to counter the Covid-19 pandemic undoubtedly have a negative impact on the economy. One of the instruments of the state, which makes it possible to save entire sectors of the economy, including the banking sector, from bankruptcy, is the stabilization loans of the central bank. Accordingly, the analysis of the discretionary powers of central banks and their governing bodies in issuing stabilization loans to overcome the economic consequences of the Covid-19 pandemic is relevant and timely. The authors used different scientific methods, such as the dialectical method, the method of comparison, the method of elementary-theoretical analysis and synthesis, the hermeneutic and the forecasting analysis. As a result of the study, the authors substantiated a definition of the powers of the governing body of the central bank in making decisions on the provision of stabilization loans to banks, as part of the function of the central bank to maintain the stability of the national currency and the indicative regulation of banks. The authors
\end{abstract}

\footnotetext{
* Doctor of Legal Science, Professor, Head of the Department of the Economic Law and Procedure of the National University «Odessa Law Academy», Corresponding Member of the Ukrainian National Academy of Law Sciences (Odesa, Ukraine). https://orcid.org/00000003-1095-3481.opp@ukr.net

** Doctor of Legal Science, Associate Professor, Department of Civil Law, Chernivtsi Law Institute National University "Odessa Law Academy" (Chernivtsi, Ukraine). https://orcid.org/0000-0002-0351-7107. christjachristja@gmail.com
} 
concluded that there is a need for an expanded approach to the limits of the discretion of the central bank, on the basis of harmonization of economic purpose of decisions on the issuance of stabilization loans to banks, in accordance with the constitution and the laws.

Keywords: Discretionary Powers, Central Bank, Stabilization Loans, Overcoming Economic Consequences, Covid-19 Pandemic

Resumen: Las medidas restrictivas impuestas por los gobiernos de todo el mundo para contrarrestar la pandemia de Covid-19 indudablemente tienen un impacto negativo en la economía. Uno de los instrumentos del estado, que permite salvar a sectores enteros de la economía, incluido el sector bancario, de la quiebra, son los préstamos de estabilización del banco central. Por tanto, resulta relevante y oportuno analizar el uso de los poderes discrecionales de los bancos centrales y de sus órganos rectores en la emisión de préstamos de estabilización para superar las consecuencias económicas de la pandemia de Covid-19. Los autores utilizaron diferentes métodos científicos, como el método dialéctico, el método de comparación, el método de análisis y síntesis elemental-teórico, el análisis hermenéutico y el uso de pronósticos. Como resultado del estudio, los autores corroboraron una definición de los poderes del órgano rector del banco central para tomar decisiones sobre la provisión de préstamos de estabilización a los bancos, como parte de la función del banco central para mantener la estabilidad de la moneda nacional y la regulación indicativa de los bancos. Los autores concluyeron que es necesario un enfoque ampliado de los límites de la discreción del banco central, sobre la base de la armonización del propósito económico de las decisiones sobre la emisión de préstamos de estabilización a los bancos, de acuerdo con la constitución y las leyes del país.

Palabras clave: Poderes discrecionales, Banco Central, préstamos de estabilización, superación de consecuencias económicas, pandemia Covid-19

Summary. I. Introduction. II. Methodology. III. Analysis of recent research. IV. Results and discussion V. Conclusions. References.

\section{INTRODUCTION}

The need to overcome the economic consequences of the Covid-19 epidemic has raised to a new level the question of the content and scope of 
public monetary policy that can stabilize the country's financial sector in a crisis of default and bankruptcy.

Central banks in advanced economies reacted swiftly and forcefully to the Covid-19 pandemic, deploying the full range of crisis tools within weeks. The initial response focused primarily on easing financial stress and ensuring a smooth flow of credit to the private non-financial sector (Cavallino \& Fiore, 2020).

In less developed countries the situation is much worse due to the weak economies and lack of powers of central banks. This is, in many cases, complicated by the dynamics of social development and changing approaches to managerial competence, which could serve as a wellestablished model for appropriate reform. This problem is especially acute in the field of banking regulation. In the modern world new legal restrictions on the freedom of capital circulation are constantly introduced, financial monitoring measures are introduced as a response of states to the globalization of economic activity, which allows to evade taxes, place assets in offshore jurisdictions, use dirty money and funds from the countries of the rehabilitation regime in financial transactions. In addition, economic systems lack unity in approaches to the independence of central banks, which may affect the specifics of monetary policy in terms of overcoming the economic consequences of the Covid-19 epidemic.

Despite different approaches, national (central) banks are considered a "state in a state" in almost every country. The role of central banks has significantly strengthened since the 2008 financial crisis and has become particularly important today in the context of the economic crisis caused by the Covid-19 pandemic.

Until recent times there were two quite different models of central banking prevailed in the past. One sees a country's central bank as the operational arm of government financial policy, its functions determined by technocratic comparative advantage. This model is rooted in central banks being the pivot of the payment system, as Francis Baring observed toward the end of the 18th century. As the banking community's team captain, they provide, in economic terms, club goods.

Under the other model, central banks are independent authorities delegated specific responsibilities and formally insulated from day-to-day politics. They provide public goods (such as price stability) and preserve common goods (such as financial stability) that can be enjoyed by all but eroded by the exploitative (Tucker, 2020).

In order to implement monetary policy, the national (central) bank is often empowered to determine the legal regime of money circulation, lending and banking supervision, and, at the same time, implements the 
appropriate monetary policy by setting a discount rate, foreign exchange market interventions, lending to commercial banks, etc. Nevertheless, the question remains whether the legal system will allow using the full potential of the regulatory influence of the country's central bank on the processes of stabilizing the crisis in the economy, in particular by providing stabilization loans to banks. In the context of public order, this means a clear definition of the limits of discretion of the national (central) bank, which can serve as a criterion for a legal assessment of its decisions and actions (inaction) of its authorized persons. The real powers of the national (central) bank in the economic system and the actual ability of governments to subordinate the decisions and actions of such banks to their current interests depend on this assessment, which may negatively affect confidence in the national currency and prospects for overcoming the economic consequences of the Covid-19 epidemic.

\section{Methodology}

The methodology of this study is based on the interaction of economic and legal analysis of legal relations in the field of issuance of stabilization loans to banks of the country by the National Bank of Ukraine (hereinafter the "NBU"), which determines the choice of methods of scientific research. The dialectical method was used to identify the dynamics of legislative consolidation of the discretionary powers of the NBU in the implementation of monetary policy.

Moreover, the method of comparison was used by the authors to identify similar and distinctive features of the discretionary powers of the NBU in comparison with the measures of indicative and administrative regulation. Using the method of elementary-theoretical analysis and synthesis, the search for moments of the essence of the discretionary powers of the central bank of the country was carried out.

The analysis and synthesis, in this case, were based on theoretical considerations about the causal relationship of economic and legal phenomena in the context of monetary policy. The method of hermeneutic analysis helped in the interpretation of legal provisions and scientific literature, allowed to identify the main definitions and categories of topics.

Furthermore, the forecasting method allows us to highlight the directions of development of discretionary powers in Ukraine in the context of overcoming the economic crisis caused by the Covid-19 epidemic, as well as to offer approaches to understanding the discretionary powers of the 
country's central bank following the needs of ensuring its independence and promoting the performance of its functions.

\section{ANALYSIS OF RECENT RESEARCH}

The question of the discretion of the central bank was considered by economists and lawyers at different times. Recent research in this area focuses on expanding the powers of national (central) banks. For example, Paul Tucker (2018) recently published a monograph «Unelected Power: The Quest for Legitimacy in Central Banking and the Regulatory State». He has made another attempt to uncover the enhanced role of central banks in the economy after the financial crisis and proposed principles that allow central banks to become good managers. There are significant contradictions between the independence of central banks in the implementation of monetary policy and the democratic limits of the delegation of powers to unelected officials.

Tucker's conclusion is that when politicians delegate policy decisions to independent, technocratic bodies, they need to do so in accordance with some key 'principles of delegation'. To date, they have not done so, and hence the crisis of legitimacy, at least as far as it applies to economic institutions. There are five design principles: there should be a clear statement of the body's purposes, objectives and powers, to stop mission creep; its operating procedures should be set out; so should its operating principles-how will it go about conducting its delegated policies; there should be sufficient transparency that the institution can be monitored and held to account by elected politicians; and there should be some rules for how it can respond to emergencies (Power and legitimacy, 2020).

Other authors note the difficulty of predicting the consequences of monetary policy, which means that there are objective risks of choosing a particular decision of the central bank (Klooster \& Fontan, 2019). On this basis, it can be argued that the powers of the central bank can be limited only in a general way: the mandate can only give general recommendations. It is no coincidence that in 2016, Clément Fontan, François Claveau, and Peter Dietsch revealed the problematic issues of liability of central banks for the economic consequences of their own decisions, which is in line with approaches to ensuring their independence. The publications of the Bank of International Settlements, which essentially summarizes the position of central banks of the world's leading countries, also focus on a high level of central bank independence in making decisions on lending rates and lending to the economy as a prerequisite for effective policy (for example, Political 
framework and legal status. Issues in the Governance of Central Banks, n.d.). Delegation of authority allows you to focus on professional and technical expertise in the central bank to implement monetary policy, increasing the expected success of the policy.

Charles Goodhart (2010) has studied the changing role of central banks. In the context of individual countries, the question of the need for flexibility of monetary policy as a means of a systematic response to time fluctuations in the previous uncertainty and heterogeneity of the private sector response to the business cycle (Tsenova, 2015) is actively raised. The doctrine of central banks law (Gortsos, 2020) is also developing due to courses and educational and practical programs on the legal framework of central banking (Legal Framework for Central Banking, n.d.; Workshop on legal frameworks for Central Banking, 2018; Legal Risks and Good Governance for Central Banks, 2014).

Marco Dani and Agustin José Menéndez (2020) in the article «The first EU measures in response to the economic consequences of the Covid19 crisis» examine the first E.U. response to the economic consequences of the Covid-19 crisis, consisting in a mix of measures including the loosening of state-aids and budgetary constraints on national economic policies, temporary purchases of national public debt by the European Central Bank, a set of loans assisted by conditionality and transfers of limited amount based on the EU budget.

The role of central banks in mitigating the effects of the global recession caused by the Covid-19 pandemic is currently being discussed (Collins \& Gagnon, 2020). In particular, it is noted that they are using all the tools in their armory to support banks so that they, in turn, can support businesses and families struggling to survive. Monetary policy interventions, delays and waivers on the application of banking regulations, and relaxation on the supervisory expectations on the application of some accounting rules - these are all coming into play (Central Banks respond to Covid-19, 2020).

In the context of Ukraine, such a discourse becomes important for assessing the discretionary powers of the NBU. In the national legal literature, the issues of discretionary powers of the NBU were considered in different contexts. Loyuk (2016) has studied the peculiarities of the NBU's discretion in establishing banks and focuses on the problems of such discretion, which on the one hand allows increasing the efficiency of the NBU, its institutional capacity, and on the other hand points to the threat of corruption.

Kobylnyk (2015), recognizing the positive features of the independence of the NBU's powers, points to the need to determine at the 
legislative level the limits within which the relevant authorities should act. Unfortunately, the question of what these limits should be-remains unresolved, as their very existence contradicts banking discretion in the economic sense. The difficulty of resolving this issue is also influenced by the fact that traditionally in post-Soviet countries there is a replacement of the understanding of the concept of "regulation" by the concept of "administrative coercion". This artificially takes economic incentives beyond regulation, although de facto such central bank activities are also regulatory. If we are talking about the division of regulatory and supervisory functions in the financial market, then, as a rule, the regulation includes the assessment of the state, establishment, and improvement of norms and rules for the provision of financial services; supervision and control over compliance with established norms and rules; taking measures to influence violators of established norms and rules (Khorunzhiy, 2016). The issues of the NBU's lending activity for refinancing the banking sector under this approach remain almost not covered by discretionary limits. The question of the limits of the NBU's discretion should be decided concerning each type of administrative competence of the NBU. This should allow for a systematic solution to the question of the extent to which the NBU should exercise its discretion in deciding to provide stabilization loans to Ukrainian banks to overcome the economic consequences of the Covid-19 epidemic.

\section{RESULTS AND DISCUSSION}

The legislative basis for the powers of the NBU in making decisions on the issuance or refusal to issue stabilization loans to banks of Ukraine is determined by the provisions of Articles 19, 99, 100 of the Constitution of Ukraine (1996), 7, 15, 42, 55 of the Law of Ukraine "On the NBU" (1999) and 66, 67, 71 of the Law of Ukraine "On Banks and Banking" (2000). It follows from the provisions that ensuring the security and stability of the banking system is the main function of the NBU. According to Art. 99 of the Constitution of Ukraine, ensuring the stability of the currency is the main function of the central bank of the state. The Constitutional Court in the decision of May 11, 2010, in item 3.2 directly pointed out that concerning the performance of the function of ensuring the stability of the national currency, "the NBU contributes to the stability of the banking system" (Judgment of the Constitutional Court of Ukraine in the case on the constitutional petition of the President of Ukraine $n^{\circ}$ 13-rp, 2010).

Stabilization loans should be recognized as a special form of refinancing loans, which, unlike other forms of refinancing, are issued for a 
long period (Support of liquidity of the banking system by the NBU, 2009). In economic doctrine, it is generally accepted that conducting the relevant monetary policy, the NBU, along with regulatory refinancing instruments, uses specific methods of refinancing - the provision of stabilization credit (Kuzmak, 2010). NBU stabilization loan refers to refinancing mechanisms used by the NBU "for effective regulation of the money market, liquidity management of the banking system, acting as a lender of last resort... Stabilization loan is intended for special needs and is not used for commercial bank lending operations" (Garkusha, 2016; Moroz \& Pukhovkina, 2005).

During 2014-2015, the NBU conducted an unprecedented campaign to support banks' liquidity by providing them with refinancing in the amount of UAH 132.9 billion. This allowed to some extent to stabilize the situation in the financial market of Ukraine (Shulga, 2016). The provision of stabilization and other loans to banks in this context was carried out to implement the provisions of Art. 99 of the Constitution of Ukraine the main function of the NBU to ensure the stability of the national currency and the corresponding details of this function in the Basic Principles of Monetary Policy of the NBU, as well as other functions of the NBU defined in the Law of Ukraine "On the NBU" (1999). In the context of counteracting the economic recession caused by the Covid-19 economic epidemic, the NBU not only reduced the discount rate but also increased the maturity of the main operations to regulate banks' liquidity, namely refinancing loans in weekly tenders, from 30 to 90 days.

In establishing the legal limits of the NBU's powers to decide on the provision of stabilization loans to banks in Ukraine one should, above all, take into account the provisions of Art. 1, 7, 15, 25, 36, 42, 68, 73 of the Law of Ukraine "On the NBU" (1999), which do not provide for the need for any coordination of the NBU issues of stabilization loans with the Cabinet of Ministers of Ukraine or other public authorities or local governments. In turn, enshrining in the Law of Ukraine "On the NBU" the competence of the NBU to lend to commercial banks indicates in favor of the fact that when issuing stabilization loans NBU as a state body acts under the special permit type of legal regulation provided by Art. 19 of the Constitution of Ukraine: "only what is expressly provided by law is allowed."

Art. 19 of the Constitution of Ukraine does not mention the provisions of bylaws in determining the legal personality of public authorities. Public authorities and local governments, their officials are obliged to act only on the basis, within the powers and in the manner prescribed by the Constitution and laws of Ukraine. This also applies to the NBU, since according to the 
Law "On the NBU" (1999) the NBU is "the central bank of Ukraine, a special central government body, whose legal status, tasks, functions, powers, and principles of organization are determined by the Constitution of Ukraine, this Law and other laws of Ukraine".

The scope of the central bank's competence in issuing stabilization loans to banks should be effectively implemented following the most common theory of a legal entity through the analysis of the competence of the governing body - the NBU board as its main body. The provision of Art. 14 of the Law "On the NBU" (1999) defines the functions of the NBU Board "through appropriate monetary instruments and other means of banking regulation" to ensure the implementation of monetary policy. The decision of the NBU Board to issue stabilization loans is aimed at using the NBU's credit resources to support Ukraine's banking system as an important part of its economy. Due to such means, the state pursues an economic policy in general. Not accidentally, under the provisions of Art. 10 of the Commercial Code of Ukraine (2003), monetary policy is one of the main directions of state economic policy.

It should be noted that under the provisions of Article 66 of the Law of Ukraine "On Banks and Banking" (2000) state regulation of banks is carried out by the NBU in the following forms: administrative regulation and indicative regulation. At the same time, administrative regulation includes, in particular, the establishment of requirements and restrictions on the activities of banks, application of sanctions of administrative or financial nature, supervision of banks. And refinancing of banks, along with such means of stimulation as the definition of interest rate policy, operations with securities on the open market, foreign exchange interventions, etc., is referred to as indicative regulation.

Such legislative provisions focus on the fact that the administrative regulation carried out by the NBU in the person of the Board is manifested mainly in the form of legal regulation and governmental administrative decisions in the process of law enforcement. Accordingly, indicative regulation takes the form of current management decisions of the NBU Board and is determined by the need to stimulate the country's financial and banking system, have a dynamic economic nature.

Regulatory provisions cannot be used for indicative regulation, as the professionalism and art of managing the monetary system depend on many factors of financial and economic reality, the combination of which cannot be provided by law and a way to decide on each case, especially a crisis one.

Similarly, administrative regulation is based on the application of legal provisions, as it provides for supervision by the NBU of compliance with banking legislation, sanctions, and other administrative coercion, which can 
not exist outside the legal obligations of banks under Ukrainian law. At the same time, indicative regulation is based on economic analysis and market methodology.

The decision to provide stabilization loans takes the form of indicative regulation based on operational and management decisions of the NBU Board, which requires professional economic analysis, financial evaluation, and professional economic judgments of responsible employees.

In the field of administrative regulation and indicative regulation, the discretion of the NBU officials is obviously of a different nature.

Being an administrative activity, administrative regulation is based on the so-called "administrative discretion". Administrative discretion exists within clear legal requirements and is mainly a form of law enforcement. In the legal doctrine the administrative discretion is defined as the legally permitted intellectual and volitional activity of a competent entity, the content of which is to choose one of several options established by law to ensure legality, fairness, expediency, and effectiveness of administrative regulation (Baadzhi, 2016).

As for the indicative regulation, which is purely economic in nature, the freedom of decision-making by the authorized person is traditionally assessed in terms of "normal production risk".

In both cases, the authorized persons act based on managerial discretion. But in the case of indicative regulation, including when deciding on the issuance of a stabilization loan, this discretion has a much broader basis, as it involves a subjective assessment of risks, provides a free choice of an economic model of the monetary system, credit terms, its volume, subproject composition and forms of collateral, the impact on related banking relationships, the availability of free credit resources, access to external borrowing, investor confidence and other variables. These variables take management activities out of indicative regulation from the enforcement regime.

This state of the relationship between legal boundaries and economic freedom is traditionally explained in legal science by the mismatch of legal and economic relations, legal and administrative requirements. The law cannot regulate the entire scope of public relations, to fully determine the behavior of the subjects of public relations - in society, there are many other regulators, including managerial, economic, political, and other. The decision to issue stabilization loans corresponds to the economic nature of management decisions and is determined only by the general limits of legal obligations. Legal norms, in this case, set only direct restrictions on the implementation of the NBU's management competence, but are not intended 
to determine the content of the management decision on indicative regulation.

The Law of Ukraine "On the NBU" (1999) provides for exceptional restrictions on the powers of the NBU, which must be taken into account when issuing stabilization loans. According to part 2 of Art. 25 of this Law "The National Bank has the right to provide loans for refinancing of the bank if it does not entail risks to the banking system." Under paragraph 1 of part 1 of Art. 42 of the Law, the National Bank to ensure the performance of its functions... "provides loans to banks to maintain liquidity at a rate not lower than the refinancing rate of the National Bank and in the manner prescribed by the National Bank."

When issuing a stabilization loan, the NBU acts primarily as a lender, entering into credit-binding relations with banks. The special legal personality of the NBU in these private-legal relations is also limited by the grounds for recognizing the transaction as invalid in the provisions of the Civil and Commercial Codes of Ukraine. Moreover, the freedom to conclude contracts as a private law principle in this case requires the interpretation of legislative provisions as dispositive following the provisions of Part 3 of Art. 6 of the Civil Code of Ukraine (2003) (Podtserkovnyi, 2004). For example, direct intent to harm the state would be contrary to the principles of public order under Art. 208 and Art. 228 of the Civil Code of Ukraine (2003), and therefore would allow to assess the decision of the Board of the NBU as illegal, which would entail the invalidity of the transaction.

Certain restrictions on contractual freedom must be taken into account when issuing stabilization loans based on the Law of Ukraine "On Banks and Banking" (2000), for example, Art. 53: "Banks are prohibited from concluding agreements to restrict competition and monopolize the terms of loans".

Indicative regulation is based on greater discretion than in the case of administrative regulation of the central bank in the implementation of monetary policy. At least, approaches to the assessment of indicative regulatory measures by the NBU should take into account established approaches to the discretion of public authorities in the exercise of power functions.

The discretionary nature of decisions on the provision of stabilization loans is since this instrument of the NBU refers to economic methods of monetary policy, which "aim to change the relevant characteristics of money circulation and credit relations through the creation of an appropriate economic and legal environment, introduction of incentives and strengthening the motivation for the necessary behavior of the subjects of the monetary sphere" (Gudzovata, 2018). 
According to the Recommendations of the Committee of Ministers of the Council of Europe $n^{\circ} \mathrm{R}(80) 2$ on the exercise by administrative authorities of discretionary powers adopted by the Committee of Ministers on 11 March 1980 at its 316th meeting, discretionary powers should be understood as the powers that an administrative body, in making a decision, can exercise with a certain discretion, (when such a body can choose from several legally permissible decisions what it considers best in the given circumstances) (Morozov, 2017).

The resolution of the Plenum of the Supreme Court of Ukraine of October 24, 2008 of $n^{\circ} 13$ states that even a court may not replace a state body acting in its discretion, take instead of a decision that is considered illegal, another decision that would comply with the law, and give instructions, which would indicate the resolution of issues within the competence of such a subject of power, as such actions go beyond the powers assigned by the legislator.

According to paragraph 1.6 of the Methodology of anti-corruption examination, approved by the order of the Ministry of Justice of Ukraine on April 24, 2017, $\mathrm{n}^{\circ} 1395 / 5$, discretionary powers is a set of rights and responsibilities of public authorities and local governments, persons authorized to perform state or local government functions, providing the opportunity at its discretion to determine in whole or in part the type and content of the management decision, or the ability to choose at its discretion one of several options for management decisions provided by the normative legal act, the draft normative legal act.

Thus, discretion is a necessary component of management. It is related to the authorities and their bearers: public authorities and local governments and their officials. As noted in scientific research, "discretion cannot be equated only with formalized powers - it is characterized by the lack of unambiguous regulation of the actions of the subject. He cannot evade the exercise of his competence, but he has no right to go beyond it" (Morozov, 2017).

That is, discretionary powers are the legally established competence of government entities, which determines the degree of independence of its implementation, taking into account the principle of the rule of law; these powers consist in the application by the subjects of administrative discretion in the implementation of actions and decision-making. In a narrower sense, discretionary power is the ability to act at one's discretion, within the law, the ability to apply the law and perform specific actions (or actions) among others, each of which is relatively correct (legal). A similar legal position is contained, for example, in the decision of the Supreme Court of Ukraine of 21.05.2013 $\mathrm{n}^{\circ} 21-87 \mathrm{a} 13$. 
Discretionary powers of the NBU in issuing stabilization loans due to the economic essence of indicative regulation determine additional elements of the freedom of choice of economic decision by the NBU. Within this freedom, the Board of the NBU gets the right to act at its own discretion, guided by the economic category of expediency. This approach is very important for prompt and balanced response to threats to the stability of the banking system in the context of the Covid-19 pandemic.

The parameters of such expediency cannot be determined in a legal order, as it is impossible to fully assess the economic factors that determine the decision in the field of indicative regulation, accurately predict the reaction of investors to the pandemic threats Covid-19, it is impossible to make an absolute assessment of the state of the economic situation in conditions of limited information about social, political, informational and other components, to accurately predict the results of indicative regulation during the economic crisis.

It is no coincidence that, according to the established approaches formed in the legal system of Ukraine, including the practice of the Supreme Court of Ukraine, expediency is not subject to judicial assessment, but is purely an element of discretionary powers of the relevant state body. The Supreme Court of Ukraine noted in its decision that "the expediency of decisions of state bodies is not subject to judicial review. The court cannot replace the relevant state body" (Supreme Court, Resolution in the composition of the panel of judges of the Administrative Court of Cassation on March 20, 2019, $\mathrm{n}^{\circ}$ 826/14951/18, 2018).

From the standpoint of the expediency of the NBU Board's decision to issue a stabilization loan, this means not only the formal non-interference of jurisdictional bodies in the NBU's competence in indicative regulation but also the actual inability of jurisdictional bodies to conduct economic analysis. The latter is the exclusive competence of the NBU in the person of its authorized bodies.

It should be borne in mind that "stabilization credit as a regulatory tool is mostly used in crisis conditions of unstable functioning of the money market" (Gudzovata, 2018).

In this context, the issue of issuing stabilization loans to Ukrainian banks is a management response of the special authorized state body (NBU) to the crisis in the banking system. The very existence of such a crisis, which today has become global and well-known due to the Covid-19 pandemic, necessitates crisis decisions that cannot be rigidly enshrined in legal proceedings.

In addition, if the NBU Board was in danger of declaring illegal any decision to issue a stabilization loan in connection with the by-laws, then the 
stability of banking regulation and predictability of market relations would be violated. In turn, such an interpretation would in itself be an element of monetary policy instability.

In this context, economists define the term "instrumental independence" of the central bank, which consists in the freedom to choose and apply the instruments of monetary policy" (Danylyshyn, 2017). Independence, "the most important condition for the efficiency of the central bank" (Baranovskyi, 2010).

The normal production risk of making decisions on bank refinancing increases for the NBU precisely in overcoming the crisis in the banking system of Ukraine. For example, in conditions of instability of the bank system the right to make decisions on the issuance of stabilization loans, including in the presence of ambiguity in the interpretation of certain powers of the NBU Board in comparison with bylaws issued by the NBU Board, in particular in the relevant Regulation (Regulations on granting stabilization loans to banks, 2014) and Technical Procedure (Technical procedure for conducting operations on granting by the NBU, 2010), fully fits into the right to introduce temporary features of indicative regulation, and hence the issuance of stabilization loans (refinancing).

The form of temporary features of indicative regulation in the laws of Ukraine is not limited, but given the above reasons of expediency, the presumption of freedom of contract, the exclusive nature of the law prohibitions on refinancing, it by its nature requires initiative and creativity, and therefore industrial risk and possible errors.

The presence of relevant crises in the economy in 2014 has prompted the legislator to enshrine in the Law of Ukraine "On the NBU" the rules that serve as a legal basis for operational and emergency powers of the NBU in ensuring the stability of the banking system in these conditions. In particular, in accordance with Article 7-1 of this Law, the NBU "in the presence of signs of the unstable financial condition of the banking system, the emergence of circumstances that threaten the stability of the banking and/or financial system, has the right to determine temporary features of regulation and supervision of banks or other persons object of inspection of the NBU, including the features of maintaining bank liquidity, application of economic standards, formation and use of reserves to compensate for possible losses on active operations of banks, introduce restrictions on their activities, including restricting or prohibiting the issuance of funds from current and deposit accounts of individuals and legal entities, as well as to restrict or temporarily prohibit foreign exchange transactions on the territory of Ukraine, in particular operations on export, transfer, and transfer of foreign currency values outside Ukraine." As can be seen from these provisions, the 
legislator recognized the NBU's right to introduce temporary features of the implementation of the NBU's powers, which apply to all forms of banking regulation: administrative and indicative. These provisions must be used effectively in a Covid-19 pandemic.

To assess the ratio of legal and by-law issuance of stabilization loans one should take into account the purpose of the relevant acts, their subject, substantive mechanism, and the range of subjects of application in conjunction with the discretionary powers of the NBU Board in this area. Given that the by-laws regulating the procedure for issuing stabilization loans must provide indicative regulation, it cannot be accompanied by the obligation of the NBU to issue a stabilization loan under certain formal conditions. Therefore, the purpose of enshrining the bylaw on the issuance of stabilization loans to Ukrainian banks is narrowed to the level of procedural requirements to encourage applicants to provide the NBU with the fullest possible information about its solvency and prospects for stabilizing its banking crisis, debt to depositors and other circumstances. This information is necessary for the NBU Board to make the most prudent decision in the current financial and economic situation due to the Covid-19 pandemic, assuming that the risk of making an ineffective decision is quite high.

If the norms of by-laws issued by the NBU Board could be considered as procedural binding norms of legislation, which must be strictly observed by the NBU Board when deciding on the issuance of stabilization loans, then such a decision would become automatic - when the applicant by the bank apply certain exhaustive documents the corresponding refusal would be impossible. Nevertheless, such automatic granting of loans cannot be imagined. The point here is a reasonable amount of discretion in carrying out management activities and making economic and managerial decisions, which is exactly the decision to provide a stabilization loan. The assumption of continuous legalization of the process of issuing stabilization loans would translate the relevant issuance into the "ATM mode", which must issue money when performing certain strictly defined technical parameters of input. This, in turn, would mean the futility of monetary policy measures, the leveling of the managerial talent of NBU managers, and the removal of political responsibility from the NBU and its Board for ineffective implementation of such policies in the context of the Covid-19 pandemic.

Possible procedural violations of the bylaw on the issuance of stabilization loans may not automatically mean the illegality of the decision of the NBU, taken in a particular situation. To address this issue, it is advisable to refer to the practice of administrative proceedings to assess certain procedural violations in the implementation of public policy. For 
example, the higher judicial authorities of this jurisdiction have formulated a position according to which procedural violations committed during the appointment and/or on-site inspection by the controlling body should not be perceived as unconditional evidence of the illegality of tax notices-decisions made as a result of the inspection. They are subject to assessment in terms of the extent to which the relevant violations have affected the taxpayer's ability to protect their rights (On generalization of judicial practice of the Supreme Administrative Court and the Supreme Court of Ukraine on appeals against inspection orders and inspection reports, 2014).

In the context of a stabilization loan, this means that procedural violations cannot be taken as unconditional evidence of the illegality of the decision, but must be assessed in terms of the extent to which such violations could affect the information and motives of the NBU Board in deciding on a stabilization loan.

Bylaws in this area are adopted by the NBU to introduce the procedure for obtaining a stabilization loan from the bank within certain procedural limits of information exchange, which are primarily substantive rather than formal. Formal compliance with any lending transactions by its very nature cannot determine the content and in any way determine the positivity of the NBU decision. After all, the actual side of the case is determined not by the number and name of documents following the procedural components of bylaws, but by the content of the aggregate information submitted to the NBU by the applicant to justify obtaining a stabilization loan.

Violations of the law when applying for a stabilization loan may be of various kinds, such as signing documents by a person who is not authorized by the constituent documents of the applicant bank, or other violations that may be obvious by NBU employees. This also applies to the inaccuracy of information that can be detected by the NBU staff when submitting documents by the applicant bank.

The incompleteness of the package of documents as a ground for leaving without consideration of the application and documents of the bank to provide a stabilization loan cannot be interpreted in isolation from the rules of bylaws that determine the list of facts that must be confirmed by relevant documents.

It is necessary to assess the content of bylaws in this context, given that the procedures defined by the NBU are aimed at the conscious and effective exercise of discretionary powers by the Board, and not at restricting the NBU in exercising these powers in comparison with the Law. In other words, the NBU Board cannot be restricted in taking measures to stabilize the banking system of Ukraine only because, in the procedural provisions of certain acts adopted by the NBU Board itself, there is ambiguity in 
understanding the right or obligation of the NBU Board to decide or refuse to issue a stabilization loan from the Bank of Ukraine. Therefore, doubts as to whether or not the NBU Board has the discretion to decide whether or not to issue a stabilization loan should always be used in favor of such a right, unless otherwise prohibited by the Constitution or laws of Ukraine.

If the NBU Board had been severely constrained in deciding on the issuance of stabilization loans, in the conditions of the highest degree of dynamics of money circulation and banking operations, including those caused by the Covid-19 pandemic, it would not have been able to quickly decide on the application of indicative regulatory measures in the banking sector, which would jeopardize the functioning of the economy as a whole and the prospects of support for the banking sector by the NBU during the recession. This means that in the absence of the NBU Board's right to interpret the procedure for issuing stabilization loans in its own discretion, taking into account the need to change the current situation with the probable threat of registration with the Ministry of Justice of Ukraine, the functions of the National Bank Board would be reduced to functions of the treasury, which issues money on clear grounds, instead of making effective stabilization decisions in the banking system. Such an assumption should be rejected even more if we pay attention to the fact that the legal status of the NBU Board, defined in the Constitution and laws of Ukraine, does not provide for such restrictions.

To determine the validity of the restriction or increase of the rights of central banks in the era of Covid-19 it is appropriate to use test proportionality.

Proportionality test can be viewed as a set of rules for determining the necessary and sufficient conditions for a limitation of a constitutionally protected right and ascertaining whether these conditions are satisfied. The proportionality test consists of four steps or sub-tests. A limitation of a constitutional right by a legal act is constitutionally permissible if and only if:

a) the act pursues a legitimate aim (legitimacy test);

b) the act is capable of achieving this aim (suitability test);

c) the act impairs the affected right as little as possible (necessity test); and,

d) the importance of achieving the aim outweighs the importance of preventing the limitation on the affected right (balancing test or proportionality stricto sensu).

If these conditions are satisfied, the test concludes that the right under consideration has greater weight and should prevail over the conflicting right. 
In our opinion from the point of view of the test of proportionality the increase of discretionary powers of central banks to overcome the consequences of the pandemic, is quite justified.

If our societies want to maintain the institution of central bank independence as a way of committing to monetary system stability and the fiscal separation of powers, and if we want to be able to reinstate independence after the pandemic crisis, care is needed. Paul Tucker (2020) names five steps:

(i) An exit route from being the finance ministry's operational arm back to independence once the pandemic has passed, and defensible decision-making authorities meanwhile

(ii) Revision of monetary regimes to allow stabilization policy to operate when the zero lower bound might bite more frequently (if productivity growth does not rebound)

(iii) A review of stability mandates, including a general policy regime for shadow banking, a legislated standard for financial system resilience, a statutory bar on lending to fundamentally broken financial firms, and increased independence from the industry - such a package might have impeded the rash of imprudent deregulatory measures introduced over the past few years, which left trading markets overleveraged when the pandemic crisis broke

(iv) Restraint by central bankers, limiting themselves, when independence is operative, to the mission of preserving monetary system stability rather than offering to solve all society's problems

(v) Widespread vigilance and awareness of subtle but cumulative attempts to repoliticize central banking to serve sectional interests - what is cheered today might bring tears tomorrow. Politics is an opportunistic trade, and there is scant scrutiny of the subtleties of monetary institutions.

\section{Conclusions}

1. In the context of overcoming the economic consequences of the Covid-19 pandemic, there is a growing need to expand the discretionary powers of central banks around the world, including Ukraine, by harmonizing the economic purpose of decisions on stabilization loans to banks and their legal form following the Constitution and laws. Such harmonization involves the application of the methodology of the economic interpretation of the law, which determines the powers of the governing body of the central bank when making decisions on stabilization loans to 
banks as part of the central bank's function of maintaining the stability of the national currency and indicative regulation of banks.

Concerning Ukraine, the legal restrictions for the NBU Board to be taken into account when making decisions on stabilization loans should be assessed as having an exceptional nature of risk avoidance for the banking system of Ukraine and the need to comply with the NBU refinancing rate. Any expansive assessment of such restrictions could jeopardize the central bank's independence and the ability of the central bank to effectively implement its statutory banking functions in the context of the economic crisis caused by the Covid-19 pandemic.

2. Bylaws of the NBU on the provision of stabilization loans to banks in Ukraine should be considered as aimed at establishing a procedure for submitting documents by the bank applying for a stabilization loan, and not establish the obligations of the NBU Board to make a decision. The Board of the NBU is guided by the needs of the banking system and the expediency of taking appropriate measures in the economic crisis as a primary basis for determining the limits of discretion in the provision of stabilization loans to banks in Ukraine.

3. Continuous legalization of the process of issuing stabilization loans by the country's central bank cannot be the basis of economic and legal policy of the state, as it would mean meaningless monetary policy measures in overcoming the economic consequences of the Covid-19 pandemic and leveling the importance of professional management in monetary policy in a crisis. Agreeing with Paul Tucker, it should be noted that whatever the current pressing expedients, which are obviously very real and urgent, it is worth preserving the integrity and independence of our institutions in the longer run. 


\section{REFERENCES}

Baadzhi, N. A. (2016). Guarantees of legality of application of administrative discretion in activity of bodies of public administration. South Ukrainian Law Journal, 1, 140-143.

Baranovskyi, O. (2010). Regulation and supervision in the banking sector: quo vadis? Bulletin of the NBU, 7, 3-10.

Cavallino, P. \& Fiore, de F. (2020). Central banks' response to Covid-19 in advanced economies. BIS Bulletin, 21. In https://www.bis.org/publ/bisbull21.pdf

Central Banks respond to Covid-19. (2020). Frontiers in Finance, 62. In https://assets.kpmg/content/dam/kpmg/xx/pdf/2020/05/frontiers-in-finance.pdf.

Collins, C. G. \& Gagnon, J. E. (2020) A timeline of central bank responses to the Covid19 pandemic. Peterson Institute for International Economics. In https://www.piie.com/blogs/realtime-economic-issues-watch/timeline-centralbank-responses-covid-19-pandemic.

Dani, M. \& Menéndez, A. J. (2020). The first EU measures in response to the economic consequences of the Covid-19 crisis. Biolaw Journal-Rivista di Biodiritto, $1 S$, 527-539.

Danylyshyn, B. (2017). Why do we need the independence of the NBU? $N V$. In https://nv.ua/ukr/opinion/svit-palatsam-vijna-kotedzhiv-v-diji-1599667.html.

Decision of the Supreme Court of Ukraine $\mathrm{n}^{\circ} 21-87 \mathrm{a} 13$. (2013). Law and business. In https://zib.com.ua/ua/39065-postanova_vsu_vid_21052013_2187a13_tekst.html.

Fontan, C., Claveau, F. \& Dietsch, P. (2016). Central banking and inequalities: taking off the blinders. Politics, Philosophy \& Economics, 15, 319-357. DOI: 10.1177/1470594X16651056.

Garkusha, Y. O. (2016). Features of the mechanism of bank refinancing in Ukraine. Money, Finance and Credit: Global and National Economic Problems, 14, 755-759.

Goodhart, C. (2010). The Changing Role of Central Banks. Financial History Review, 18(2), 135-154. DOI: 10.2139/ssrn.1717776.

Gortsos, C. (2020). The Functions of Central Banks and Definition of European Central Banking Law. European Central Banking Law, 3-61. DOI: 10.1007/978-3-03034564-8_1.

Gudzovata, O. O. (2018). Substantiation of methods, tools and means of state regulation in the monetary sphere in the system of financial security of the state. Black Sea Economic Studies, 32, 43-47. In http://nbuv.gov.ua/UJRN/bses_2018_32_10.

International Monetary Fund (IMF). (n.d.). Legal Framework for Central Banking (CBLF). International Monetary Fund (IMF) Training. In https://www.imf.org/en/CapacityDevelopment/Training/ICDTC/Courses/CBLF. 
Khorunzhiy, S. (2016). Distribution of regulatory and supervisory functions in the financial market: European experience and recommendations for Ukraine. Office of Financial and Economic Analysis in the Verkhovna Rada of Ukraine. In https://feao.org.ua/wpcontent/uploads/2016/12/FEAO_Rozpodil_funktsiy_na_finrynky.pdf.

Klooster, J. van't \& Fontan, C. (2019). The myth of market neutrality: a comparative study of the European Central Bank's and the Swiss National Bank's corporate security purchases. New Political Economy, August. DOI:10.1080/13563467.2019.1657077.

Kobylnyk, D. A. (2015). Some considerations regarding the discretionary powers of bodies engaged in financial activities in Ukraine. Theory and practice of jurisprudence, 2. In http://nbuv.gov.ua/UJRN/tipp_2015_2_20.

Kuzmak, O. M. (2010). Ensuring the stability of the banking system through refinancing. Financial system of Ukraine, 287-294.

Loyuk, I.A. (2016). Features of the implementation of discretionary powers of the National Bank of Ukraine in the creation of banks. Journal of Kyiv University of Law, 2, 115-120. In http://nbuv.gov.ua/UJRN/Chkup_2016_2_28.

Methodology of anti-corruption examination: order of the Ministry of Justice of Ukraine $\mathrm{n}^{\circ}$ 1395/5. (2017). In https://zakon.rada.gov.ua/laws/show/v1395323-17\#Text.

Moroz, A. M. \& Pukhovkina, M. F. (eds). (2005). Central Bank and monetary policy. Kyiv: KNEU.

Morozov, E. (2017). Discretionary powers of the government as a basis for "legal refusal”. Legal Bulletin of Ukraine. In https://yvu.com.ua/dyskretsijnipovnovazhennya-vlady-yak-pidstava-dlya-zakonnoyi-vidmovy/.

National Bank of Ukraine. (2009). Support of liquidity of the banking system by the National Bank of Ukraine: Press release of the Monetary Policy Department of the NBU. In https://old.bank.gov.ua/control/uk/publish/printable_article?art_id=84310\&sho wTitle $=$ true.

National Bank of Ukraine. (2010). Resolution. Technical procedure for conducting operations on granting by the National Bank of Ukraine. In https://zakon.rada.gov.ua/laws/show/v0445500-10\#Text.

National Bank of Ukraine. (2018). Workshop on legal frameworks for Central Banking. Joint Vienna Institute. In https://www.jvi.org/training/course-schedules/courseschedule-2018/course/18IM12.html.

Podtserkovnyi, O. P. (2004). Deficiencies of the norms on freedom of contract in the new Civil Code of Ukraine. Bulletin of the Academy of Legal Sciences of Ukraine, 3, 77-90.

Political framework and legal status. Issues in the Governance of Central Banks. (n.d.). Bis.org. In https://www.bis.org/publ/othp04_3.pdf. 
Power and legitimacy. (2020). The Enlightened Economist. In

http://www.enlightenmenteconomics.com/blog/index.php/2018/05/power-andlegitimacy/.

Shulga, N. (2016). Refinancing of Ukrainian banks. Bulletin of KNTEU, 3, 78-88.

Tsenova, T. (2015). Monetary Policy, Heterogeneous Expectations and Uncertainty. SSRN Electronic Journal. DOI: 10.2139/ssrn.2620074.

Tucker, P. (2018). Unelected Power: The Quest for Legitimacy in Central Banking and the Regulatory State. Princeton: Princeton University Press.

Tucker, P. (2020). On Central Bank Independence. International Monetary fund. In https://www.imf.org/external/pubs/ft/fandd/2020/05/paul-tucker-unelectedpower-on-central-bank-independence.htm.

Ukraine. (1996). Constitution. In http://zakon2.rada.gov.ua /laws/show/254\%D0\%BA/96$\% \mathrm{D} 0 \% \mathrm{~B} 2 \% \mathrm{D} 1 \% 80$

Ukraine. (1999). On the National Bank of Ukraine: Law of Ukraine ${ }^{\circ}$ 679-XIV.In https://zakon.rada.gov.ua/laws/show/679-14.

Ukraine. (2000). On Banks and Banking: Law of Ukraine $n^{\circ} 2121-$ III. In https://zakon.rada.gov.ua/laws/show/2121-14.

Ukraine. (2003). Civil Code. In https://zakon.rada.gov.ua/laws/show/435-15.

Ukraine. (2003). Commercial Code. In https://zakon.rada.gov.ua/laws/show/43615/page\#Text.

Ukraine. (2008). On the practice of consideration of corporate disputes by courts:

Resolution of the Plenum of the Supreme Court $n^{\circ} 13$. In

https://zakon.rada.gov.ua/laws/show/v0013700-08.

Ukraine. (2014). Legal Risks and Good Governance for Central Banks. Christ's College Cambridge. In http://renesmits.eu/OG_digital.pdf.

Ukraine. (2014). On generalization of judicial practice of the Supreme Administrative Court and the Supreme Court of Ukraine on appeals against inspection orders and inspection reports. State Fiscal Service of Ukraine. Retrieved from http://consultant.parus.ua/?doc=0993WC0E0C.

Ukraine. (2014). Regulations on granting stabilization loans to banks: Resolution of the National Bank of Ukraine. In https://zakon.rada.gov.ua/laws/show/z045114\#Text.

Ukraine. Judgment of the Constitutional Court of Ukraine in the case on the constitutional petition of the President of Ukraine $n^{\circ} 13$-rp. (2010). In https://zakon.rada.gov.ua/laws/show/v013p710-10\#Text.

Ukraine. Supreme Court. (2018). Resolution in the composition of the panel of judges of the Administrative Court of Cassation $\mathrm{n}^{\circ} 826 / 14951 / 18$. State Register of Court Decisions. In http://reyestr.court.gov.ua/Review/80606679. 